\title{
In vitro Evaluation of Antifungal Activity of Callicarpa macrophylla Vahl. Leaves
}

\author{
YC Tripathi ${ }^{1 *}$, Nishat Anjum ${ }^{1}$ and Lokesh Upadhyay ${ }^{2}$ \\ ${ }^{1}$ Chemistry Division, Forest Research Institute, Dehradun, India \\ ${ }^{2}$ Centre for Interdisciplinary Biomedical Research, Adesh University, Bathinda, Punjab, India
}

Submission: February 21, 2017; Published: March 03, 2017

"Corresponding author: YC Tripathi, Chemistry Division, Forest Research Institute, P.O. New Forest, Dehradun - 248006, India, Tel: +0135-2224207; +91-9412050775; Email: tripathiyc@gmail.com

\begin{abstract}
Aqueous extracts of leaves of Callicarpa macrophylla Vahl. traditionally known for medicinal value were evaluated for antifungal efficacy against six pathogenic fungi namely viz, Alternaria alternata, Aspergillus flavus, Aspergillus niger, Cladosporium cladosporidies , Drechslera halodes and Fusarium moniliforme by agar-well diffusion method. The minimum inhibitory concentration (MIC) was determined through the broth dilution method which was found in the range of $3.50-4.25 \mathrm{mg} / \mathrm{ml}$. Aqueous extract of $C$. macrophylla leaves exhibited varying degrees of antifungal activity against all the six test fungi. Radial growth inhibition of at concentration of 5, 10,20 and $30 \mathrm{mg} / \mathrm{ml}$ was much less than that of positive control. However, 40 and $50 \mathrm{mg} / \mathrm{ml}$ test concentration of extract was considerably effective on growth inhibition of all the test fungi. The study thus revealed the promising antifungal efficacy of $C$. macrophylla leaves and its potential for development of botanical fungicide.
\end{abstract}

Keywords: Antifungal Activity; Callicarpa macrophylla; Leaves; Aqueous Extract

\section{Introduction}

Economic losses caused by plant diseases are one of the main problems in crop management and postharvest storage. The use of synthetic fungicides has been the major way of crop protection from fungal disease and control of postharvest decay throughout the world during the past several decades. However, enormous and unabated use of these products coupled with lack of adequate precaution and control for using them has generated numerous problems such as new fungal pathogen strains resistant to fungicides and the increase of toxic residues hazardous to ecosystem and living biota. In this context, attention has been directed to plant and plant products that may serve as no or less toxic and ecofriendly substitutes of synthetic fungicides. Plants have defensive response by means of some formed or pre-formed substances commonly called plant secondary compounds or photochemical which prevent and combat microbial attack [1]. This has prompted intensive research on the development of phytofungicides as safe alternatives to synthetic fungicides that could potentially be used in the management of plant diseases. [2]. The genus Callicarpa comprising of $>40$ species under family Verbenaceae is a rich source of biologically active photochemical and traditionally used as fish poisons, insect deterrents, and medicine for skin diseases. Callicarpa macrophylla Vahl. (Commonly known as Priyangu) is an erect shrub distributed throughout India, Nepal, Bhutan, Myanmar, South East Asia, and China [3].

In India, it occurs in the Indo genetic region and sub-Himalayan tracks upto an altitude of $2000 \mathrm{~m}$ and found in Jammu \& Kashmir, Himachal Pradesh, Uttar Pradesh, Bihar, Sikkim, West Bengal, Arunachal Pradesh, Assam, Meghalaya, Nagaland, Manipur, Mizoram, Tripura, and Andhra Pradesh states of the country $[4,5]$. The plant is popularly called as Beauty berry due to its beautiful rose-pink flowers. Various parts of the plant have been attributed to a wide spectrum of medicinal properties in Indian and Chinese systems of traditional medicine [6-8]. The plant has been investigated for its chemical constituents and biological properties. Photochemical studies have led to the isolation and characterization of a number of chemical constituents including diterpenes [9-11], flavonoids, phenylpropanoids, phytosterols, sesquiterpenes, and triterpenes [12].

Scientific reports revealed that leaves of $C$. macrophylla have anti-inflammatory [13], analgesic and, antipyretic activities [14] while its roots have anti-inflammatory and analgesic activities [15]. Our previous study had reported the presence of presence 
of steroids, terpenoids and flavonoids in petroleum ether extract; flavonoids, terpenoids, steroids and glycosides in chloroform extract; flavonoids, terpenoids, steroids, carbohydrates, proteins, amino acids, glycosides and saponins in methanol extract and flavonoids, tannins, carbohydrates, proteins, amino acids, glycosides and saponins in aqueous extract [16]. In the present research work, antifungal properties of leaf extracts of C. macrophylla against some pathogenic fungi have been studied.

\section{Materials and Methods}

\section{Collection of Plant Material}

Fresh leaves of $C$. macrophylla were collected from suburbs of Dehradun and authenticated by Systemic Botany Section of Botany Division, Forest Research Institute (FRI), Dehradun, India. A voucher specimen has been preserved in the Chemistry Division, FRI for future reference.

\section{Processing of Plant Material}

The collected leaves were properly cleaned under running tap water to remove sand and dust and then shade dried in shade for 7 days. The dried leaves were ground to coarse powder and preserved in sealed container till extraction.

\section{Preparation of Extract}

Dried and powdered leaves (100 g) were taken in a large beaker and extracted sterile distilled water (500 $\mathrm{ml} \mathrm{X} \mathrm{3)}$ through stirring with a mechanical stirrer for $8 \mathrm{~h}$. The aqueous extracts so obtained was filtered through filter paper (Whatman No.1), concentrated using rotary flash evaporator and finally evaporated to dryness to obtain water free extracts. The extracts was finally dried over anhydrous sodium sulphate and stored in sealed glass bottle and preserved at $5^{\circ} \mathrm{C}$ until further analysis.

\section{Determination of Antifungal Activity}

\section{Test Fungi}

For antifungal evaluation of C. macrophylla leaves, some important and frequently occurring pathogenic fungi viz., Alternaria alternata (AA), Aspergillus flavus (AF), Aspergillus niger (AN), Cladosporium cladosporidies (CC), Drechslera halodes (DH) and Fusarium moniliforme (FM) were selected. These fungi were isolated from the infected seeds by Standard Blotter Method [17] and identified based on growth characteristic, mycelial morphology, spore morphology and other important characters using standard protocol $[18,19]$. Pure cultures of each of the selected fungal species were made separately and maintained at on PDA slants. These pure cultures were used for antifungal assay.

\section{Preparation of Test Solutions}

Test solutions of a series of concentrations viz, 5, 10, 20, 30,40 , and $50 \mathrm{mg} / \mathrm{ml}$ were prepared from the aqueous extract of $C$. macrophylla leaves by dissolving the extract in Dimethyl sulfoxide (DMSO). All test solutions were kept in refrigerator at $40 \mathrm{C}$ till future use.

\section{Preparation of Fungal Inoculums}

For antifungal assay cultured slants were used for preparing spore suspension in $0.9 \%$ saline water. The fungal spore suspension was adjusted to give a final concentration of 1-5x105 $\mathrm{cfu} / \mathrm{ml}$.

\section{Preparation of Media}

The medium was prepared by dissolving Potato dextrose agar (PDA) media (HiMedia) in distilled water and autoclaving at $1210 \mathrm{C}$ for 15 minutes. $20 \mathrm{ml}$ of sterile PDA media was poured in sterilized petridishes ( $9 \mathrm{~cm}$ diameter) and allowed to solidify which were used for antifungal assy.

\section{Antifungal Activity Assay}

Antifungal activity of aqueous extract C. macrophylla leaves was determined using agar-well diffusion method [20]. Spore suspensions $(0.2 \mathrm{ml})$ were applied on the surface of the presterilized and autoclaved PDA petridishes and spread by using a sterile glass spreader. Wells of $6 \mathrm{~mm}$ diameter were made in centre of each of the PDA petriplates with the help of sterilized cork borer. The wells were filled with test solutions of bark extract as prepared above with three replications for each treatment. Carbendazim $(2 \mathrm{mg} / \mathrm{ml})$ and DMSO were served as positive and negative control respectively for each of the three extracts. All the petridishes including treatments and controls were allowed to diffuse at room temperature for 2 hours and then incubated at room temperature $(28 \pm 20 \mathrm{C})$ for 72 hours. After incubation, the antifungal activity of extracts was determined by measuring the diameter $(\mathrm{mm})$ of inhibition zones.

\section{Determination of Minimum Inhibitory Concentration}

The minimum inhibitory concentration (MIC) was determined through the broth dilution method [21]. Fungi were first grown in the potato dextrose broth for $24 \mathrm{hrs}$ and then the inoculums were diluted for five times (10-5dilution) to control its vigorous growth. Then each test tube was added with $1.8 \mathrm{ml}$ of potato dextrose broth and different concentrations $(1-10 \mathrm{mg} /$ $\mathrm{ml}$ ) leaf extract followed by inoculation of $0.2 \mathrm{ml}$ of respective fungi and kept at $28^{\circ} \mathrm{C}$ for $48 \mathrm{hrs}$. The tubes were examined for visual turbidity. Lowest concentrations of the extracts showing no turbidity (without microbial growth) were considered as the minimal inhibitory concentration.

\section{Results}

The antifungal activity of $C$. macrophylla leaves extract determined by the agar-well diffusion method is shown in Table 1. Minimum inhibitory concentrations (MIC) C. microphylla leaves extract for all the six test fungi were found in the range of $3.50-4.25 \mathrm{mg} / \mathrm{ml}$. It is confirmed by the results that aqueous extract of C. microphylla leaves have very low MIC values against the test fungi. 
Table 1: Zone of inhibition in test fungi with C. macrophylla leaves extract.

\begin{tabular}{|c|c|c|c|c|c|c|}
\hline \multirow{2}{*}{$\begin{array}{c}\text { Treatments } \\
\text { Conc.(mg/ml) }\end{array}$} & \multicolumn{6}{|c|}{ Zone of Inhibition(mm) } \\
\hline & AA & $\mathbf{A F}$ & AN & CC & DH & FM \\
\hline 5 & $2.33 \pm 0.19$ & $2.13 \pm 0.56$ & $2.86 \pm 0.16$ & $3.26 \pm 0.19$ & $3.66 \pm 0.43$ & $2.96 \pm 0.26$ \\
\hline 10 & $6.63 \pm 0.13$ & $5.86 \pm 0.21$ & $5.15 \pm 0.11$ & $6.25 \pm 0.15$ & $6.55 \pm 0.25$ & $5.65 \pm 0.29$ \\
\hline 20 & $13.16 \pm 0.33$ & $11.33 \pm 0.31$ & $10.79 \pm 0.21$ & $11.59 \pm 0.21$ & $12.19 \pm 0.23$ & $12.45 \pm 0.13$ \\
\hline 30 & $21.25 \pm 0.16$ & $19.85 \pm 0.21$ & $20.15 \pm 0.31$ & $21.25 \pm 0.36$ & $22.15 \pm 0.31$ & $22.19 \pm 0.33$ \\
\hline 40 & $30.16 \pm 0.21$ & $27.63 \pm 0.56$ & $28.23 \pm 0.35$ & $28.43 \pm 0.33$ & $29.13 \pm 0.23$ & $29.13 \pm 0.16$ \\
\hline 50 & $32.55 \pm 0.09$ & $31.65 \pm 0.15$ & $32.15 \pm 0.16$ & $31.25 \pm 0.16$ & $30.85 \pm 0.25$ & $31.55 \pm 0.15$ \\
\hline+ Control & $32.13 \pm 0.07$ & $32.63 \pm 0.13$ & $33.85 \pm 0.16$ & $32.83 \pm 0.15$ & $31.83 \pm 0.35$ & $31.96 \pm 0.13$ \\
\hline - Control & - & - & - & - & - & - \\
\hline
\end{tabular}

Values are given in mean \pm SD for three replicates. AA: Alternaria alternata; AF: Aspergillus flavus; AN: Aspergillus niger; CC: Cladosporium cladosporidies; DH: Drechslera halodes; FM: Fusarium moniliforme

Fungal growth inhibition results presented in Table 1 clearly indicated that the aqueous extract of $C$. macrophylla leaves exhibited varying degrees of antifungal activity against all the six test fungi. Of the different test concentrations, it is observed that inhibition of radial growth at concentration of 5, 10, 20 and $30 \mathrm{mg} / \mathrm{ml}$ is much less than that of positive control. However, 40 and $50 \mathrm{mg} / \mathrm{ml}$ test concentration of extract is considerably effective on growth inhibition of all the test fungi. The mean radial growth inhibition of test fungi Alternaria alternata, Aspergillus flavus, Aspergillus niger, Cladosporium cladosporidies, Drechslera halodes and Fusarium moniliforme with various concentrations of aqueous extract of $C$. microphylla leaves ranged between 2.33$32.55,2.13-31.65,2.86-32.15,3.26-31.25,3.66-30.85$ and $2.96-$ $31.55 \mathrm{~mm}$ respectively.

\section{Discussion}

From the result it is also evident that growth inhibition of all the fungi increased with increase in test concentration of extracts. Further, growth inhibition results in all the six test fungi is the highest at $50 \mathrm{mg} / \mathrm{ml}$ concentration of extract and are found to be higher than the positive control. Test concentration of $50 \mathrm{mg} / \mathrm{ml}$ showed growth inhibition almost at par with synthetic fungicide Carbendazim taken as positive control (Figure 1).

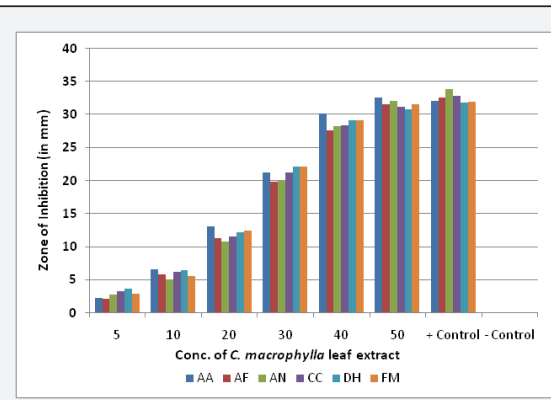

Figure 1: Antifungal activity of C. macrophylla leaves extract against test Fungi.

Phytochemical screening of aqueous extract of $C$. macrophylla leaves have reported the presence flavonoids, tannins, carbohydrates, proteins, amino acids, glycosides and saponins in aqueous extract [16]. In recent years, a number of studies have been conducted on the antifungal activity of phenolic compounds including flavones and related flavonoids glycosides, coumarins and derivatives, and anthraquinones [2226]. The antifungal potency of aqueous extract of $C$. macrophylla leaves may be due to presence of phenolic chemical constituents of complex molecular structure and diverse action mechanisms.

\section{Conclusion}

Based on the results of the study, it can be concluded that C. macrophylla leaves exhibiting antifungal activity comparable to commercially known synthetic fungicide can be a promising source of botanical fungicide. For many years, synthetic fungicides have been used to control plant diseases. Indiscriminate of such synthetic chemicals in plant protection has caused environmental contamination and toxicity to living organisms. Synthetic fungicides though being highly effective led to their repeated use that has caused severe environmental pollution, development of resistance, and residual toxicity [2730].

This has necessitated the development and promotions of ecofriendly plant derived botanical fungicides. To date, a number of plant and plant secondary metabolites have been reported to have antifungal activities. Although new fungicides based on natural plant extracts are continually developing, more research is necessary for optimizing applications and become a safe alternative for eliminating the chemical fungicides from agriculture and plantation programmes. Compared to synthetic fungicides, plant-derived herbal fungicides show relatively low or little toxicity, thus are safe and may serves as essential tools for plant disease management. In addition, botanical fungicides will play an important role in reducing environmental pollution in agricultural ecosystems. Nevertheless, studies will be required to investigate their cost, applicability, safety, and phytotoxicity against crops as potential botanical fungicides.

\section{Reference}

1. Copping LG, Menn JJ (2000) Biopesticides: a review of their action, applications and efficacy. Pest Manag Sci 56(8): 651-676.

2. Yoon MY, Cha B, Kin JC (2013) Recent Trends in Studies on Botanical Fungicides in Agriculture. Plant Pathol J 29(1): 1-9. 
3. Manandhar NP (1995) An inventory of some vegetable drug resources of Makawanpur district Nepal. Fitoterapia 66(3): 231-238.

4. Chopra RN, Nayar SL, Chopra IC (1986) Glossary of Indian Medicinal Plants. Council of Scientific and Industrial Research: New Delhi, India.

5. Manandhar NP (2002) Plants and People of Nepal. Timber Press pp: 636.

6. Billore KV, Yelne MB, Dennis TJ (2005) Database on Medicinal Plants used in Ayurveda, Central Council for Research in Ayurveda and Siddha. New Delhi 7: 353-355.

7. Khare CP (2004) Indian Herbal Remedies: Rational Western Therapy, Ayurvedic and Other Traditional Usage, Botany. Springer.

8. Kirtikar KR, Basu BD (2006)1987 Indian medicinal plants. International book Distributers 3: 1922.

9. Talapatra SK, Polley M, Talapatra B (1994) Terpenoids and related compounds. Part 32 Calliphyllin, a new diterpene from the leaves of Callicarpa macrophylla. J Ind Chem Soc 71: 527-532.

10. Singh AK, Bagchi GD, Singh S, Dwivedi PD, Gupta AK, et al. (2004) Use of phyllocladane diterpenoids for plant growth promotion and alleviation of growth retardant allelochemicals, and method thereof. US Patent 6: 673-749.

11. Goel MK, Kukreja AK, Singh AK, Khanuja SPS (2007) In-vitro plant growth promoting activity of phyllocladane diterpenoids isolated from Callicarpa macrophylla Vahl. in shoot culture of Rauwolfia serpentina. Nat Prod Commun 2(8): 799-802.

12. Tellez MR, David FE, Schrader KK, Wedge DE, Duke OS (2000) Composition and some biological activities of the essential oil of Callicarpa americana (L.). J Agric Food Chem 48(7): 3008-3012.

13. Yadav V, Jayalakshmi S, Singla RK, Patra A (2011) Preliminary assessment of anti-inflammatory activity of Callicarpa macrophylla Vahl. leaves extracts. Indo Global Journal of Pharmaceutical Sciences 1(3): 219-222.

14. Yadav V, Jayalakshmi S, Patra A, Singla RK (2012a) Investigation of analgesic \& anti-pyretic potentials of Callicarpa macrophylla Vahl. leaves extracts. Webmedcentral. Intl J Medicine and Mol Medicine 3(6): WMC003447.

15. Yadav V, Jayalakshmi S, Singla RK, Patra A, Khan S (2012b) Assessment of anti-inflammatory and analgesic activities of Callicarpa macrophylla Vahl. roots extracts. Webmedcentral Pharmacology 3(5): WMC003366.

16. Anjum Nishat, Vikas, Tripathi YC (2013) Physicochemical and Phytochemical Investigation on Callicarpa macrophylla Vahl. Leaves from Dehradun, Uttarakhand. Univ J Phytochem Ayur Heights 2(15): 13-16.

17. ISTA (1999) Proceedings of the International seed testing association International rules for seed testing. Seed Science and Technology 76: 481-484.

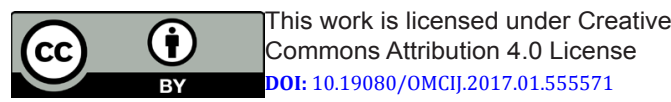

18. Barnett HL, Hunter B (2000) Illustrated Genera of Imperfect Fungi. $4^{\text {th }}$ edn. APS PRESS p: 218.

19. Mukadam DS, Patil MS, Chavan AM, Patil AR (2006) The Illustrations of Fungi. ( $1^{\text {st }}$ edn.). Akshar Ganga Prakashan, Aurangabad, India.

20. OECD (Organization of Economic Co-operation and Development) (2001) The OECD guidelines for testing of chemical and acute oral toxicity. OECD France.

21. Gatsing D, Nkeugouapi CFN, Nkah BFN, Kuiate JR, Tchouanguep FM (2010) Antibacterial activity, bioavailability and acute toxicity evaluation of the leaf extract of Alchornea cordifolia (Euphorbiaceae). Int J Pharmacol 6(3): 173-182.

22. Cho JY, Choi GJ, Lee SW, Jang KS, Lim HK, et al. (2006a) Antifungal activity against Collectotrichum spp. of curcuminoids isolated from Curcuma longa L. rhizomes. J Microbiol Biotechnol 16: 280-285.

23. Cho JY, Choi GJ, Lee SW, Lim HK, Jang KS, et al. (2006b) In vivo antifungal activity against various plant pathogenic fungi of curcuminoids isolated from the rhizomes of Curcuma longa. Plant Pathol J 22: 94-96.

24. Shin KS, Lee S, Cha B (2007) Antifungal activity of plumbagin purified from leaves of Nepenthes ventricosa x maxima against phytopathogenic fungi. Plant Pathol J 23(2): 113-115.

25. Yoon MY, Kim YS, Ryu SY, Choi GJ, Choi YH, et al. (2011a) In vitro and in vivo antifungal activities of decursin and decursinol angelate isolated from Angelica gigas against Magnaporthe oryzae, the causal agent of rice blast. Pest Biochem Physiol 101(2): 118-124.

26. Yoon MY, Kim YS, Choi GJ, Jang KS, Choi YH, et al. (2011b) Antifungal activity of decursinol angelate isolated from Angelica gigas against Puccinia recondita. Res Plant Dis 17: 25-31.

27. Bunemann EK, Schwenke GD, Van Zwieten L (2006) Impact of agricultural inputs on soil organisms - a review. Australian Journal of Soil Research 44(4): 379 - 406.

28. Arias-Estevez M, Lopez-Periago E, Martinez-Carballo E, Simal-Gandara J, Mejuto JC, et al. (2008) The mobility and degradation of pesticides in soils and the pollution of groundwater resources. Agriculture Ecosystems \& Environment 123(4): 247- 260.

29. Komarek M, Cadkova E, Chrastny V, Bordas F, Bollinger JC (2010) Contamination of vineyard soils with fungicides: A review of environmental and toxicological aspects. Environment International 36: $138-151$

30. Saxena HO, Tripathi YC, Pawar G, Kakkar A, Mohammad N (2014) Botanicals as Biopesticides: Active Chemical Constituents and Biocidal Action. In: Familiarizing with Local Biodiversity, (P.K. Khatri and P.B. Meshram Eds.), Tropical Forest Research Institute (ICFRE), Jabalpur pp: 227-246.

Your next submission with Juniper Publishers will reach you the below assets

- Quality Editorial service

- Swift Peer Review

- Reprints availability

- E-prints Service

- Manuscript Podcast for convenient understanding

- Global attainment for your research

- Manuscript accessibility in different formats

( Pdf, E-pub, Full Text, Audio)

- Unceasing customer service

Track the below URL for one-step submission https://juniperpublishers.com/online-submission.php 